\title{
Detection of Paenibacillus larvae Spores in the Debris and Wax of Honey Bee by the Tween 80 Method
}

\author{
J. BZDIL \\ State Veterinary Institute Olomouc, Olomouc, Czech Republic \\ Received February 14, 2007 \\ Accepted October 2, 2007
}

\begin{abstract}
Bzdil J.: Detection of Paenibacillus larvae Spores in the Debris and Wax of Honey Bee by the Tween 80 Method. Acta Vet. Brno 2007, 76: 643-648.

The aim of the present study was to validate a new method of detection of Paenibacillus larvae spores in the debris and wax of honey bee and compare it with the method commonly used in the Czech Republic, i.e. the method based on dissolving wax components of samples in toluene or benzene and releasing them in a liquid medium. The new method builds on homogenization of the material at the temperature of $70 \pm 2{ }^{\circ} \mathrm{C}$, using distilled water and homogenization agent Tween 80. The spores are transferred from the suspension thus created to a liquid medium diluted and treated by heat $\left(90 \pm 2{ }^{\circ} \mathrm{C}\right)$ in order to destroy vegetative saprophytic microflora. This medium is then inoculated on solid culture media (blood agar and MYPGP with nalidixic acid) at individual doses of $0.2 \mathrm{ml}$. After five to eight-day incubation at $37 \pm 1{ }^{\circ} \mathrm{C}$, the suspected $P$. larvae colonies are counted and subjected to confirmation. The count of colonies multiplied by 100 represents the number of spores in $1 \mathrm{~g}$ of the material. Eleven debris control samples from circular test and 10 demonstrably positive debris samples containing P. larvae spores were used to compare both methods. The new method was independently tested on other 1,509 field samples of winter debris collected in protection areas around American foulbrood (AFB) outbreaks and examined from 1 January 2006 to 10 May 2006. Of these 1,509 field samples, 46 were $P$. larvae positive. The comparison of the number of spores found concurrently by both methods in 21 control samples and their benchmarking by the paired $t$-test method showed that the Tween method was significantly more effective in detection of $P$. larvae spores in the examined material than the commonly used Toluene method (the $t$ value was -3.524 ). The test results indicate that the Tween method, as soon as it is tested and validated at other research sites, can be effective in examining the debris and wax of honey bee. Unlike Toluene method based on organic solvents, the Tween method is more acceptable from the point of view of fire protection, environment compatibility, waste disposal and occupational health and safety of laboratory staff. From the scientific perspective, the Tween method could play an important role in early diagnostics and subsequent control of the incidence of American foulbrood not only in the Czech Republic, but also in other countries worldwide.
\end{abstract}

Homogenization, spore, identification, antagonist, control, quantitative

Various methods of detection of $P$. larvae in various bee products have been reported in literature. Most commonly, brood samples are used as culturing material. Hansen and Brødsgaard (1999) report that $P$. larvae survive for many years in larval food, soil and debris of dry larvae. Tests showed that the spores retain their germinative activity for up to 35 years. For routine diagnostics of American foulbrood, Hansen and Brødsgaard recommend using preparations (stained according to Gram) in light field microscopy and spores in phase contrast microscopy. They advise to use J-agar and MYPGP agar as culture media. They describe similar methods to be used for detection of the spores in honey and recommend supplementing the atmosphere with $5 \% \mathrm{CO}_{2}$ during the incubation of plates. Hornitzky and Nicholls (1993) suggest that microbiological examination of honey samples is a useful tool for detection of the onset of American foulbrood in bee colonies. These authors evaluated the effectiveness of detection of $P$. larvae in three different selective solid media, namely sheep blood agar (SBA), J-medium and Brain

Address for correspondence:

MVDr. Jaroslav Bzdil

State Veterinary Institute Olomouc

Jakoubka ze Stříbra 1

77900 Olomouc

Czech Republic
Phone: +420-585 557223

$+420-58555711$

Fax: +420 585222394

E-mail: vetmed@seznam.cz

http://www.vfu.cz/acta-vet/actavet.htm 
Heart Infusion Agar (BHIA). Nalidixic acid at the dose of $3 \mu \mathrm{g} / \mathrm{ml}$ was used as a selective component in all media. Experiments of Hornitzky and Nicholls showed that the most effective medium for detection of $P$. larvae is J-medium. Alippi (1995) reported using new media for microbiological examination of honey samples. These media were prepared by supplementing J-agar with antibiotic supplements of nalidixic acid and pipemidic acid. The results of Alippi's study indicate that media supplemented this way reliably prevent the growth of other bacillus species that occur on the plates before P. larvae start to germinate. Gochnauer and Conner (1974) point out the possibility of bee colony infection by contaminated pollen fed to healthy bees. Also, they believe it is necessary to examine surplus pollen that is to be further used or sold. Another material suitable for detection of Paenibacillus larvae spores, the causative agent of American foulbrood, is bee debris. It is possible to detect spores in the debris during clinical manifestation of the disease, as well as in the stage when the agent is present in the beehive but has not caused any clinical manifestations yet. This can be extremely important for prevention and control of incidence and spread of the infection. The method of bee debris examination was published by Titerra and Haklová (2003). Although this method became recognized and commonly used within the process of diagnostics of American foulbrood in the Czech Republic, it proved to be questionable in some practical aspects. In their study, Titěra and Haklová (2003) state: "In the Czech Republic, all bee colonies in protection areas around American foulbrood outbreaks are obligatorily inspected. Clinical inspections performed by specialists are very high-powered and expensive. We developed a method of Paenibacillus larvae detection in winter debris from beehives for purposes of exact localization of diagnostic clinical inspections. This method has been validated in comparison with results of clinical findings and microbiological evaluations of sugar stores in colonies." Titěra and Haklová (2003) report that the aforementioned method is based on the collection of $1.5 \mathrm{~g}$ of debris from the bottoms of beehives and dissolution of the sample in organic solvent (10 $\mathrm{ml}$ of toluene). Then $2 \mathrm{ml}$ of liquid part of the sample is put in $6 \mathrm{ml}$ of $0.7 \% \mathrm{NaCl}$. The mixture is shaken well, inoculated in Petri dishes and cultured for 7 days on MYPGP agar with nalidixic acid $(30 \mathrm{mg} /$ litre) suppressing the growth of non-target microbes. The authors believe that this method is a significant aid in process of radical eradication of AFB foci. Haklová et al. (2006) also draw attention to the importance of an early and exact diagnosis of the $P$. larvae incidence within the programs of the AFB control. They recommend using MYPGP agar with nalidixic acid for culturing brood, comb, debris and honey samples. Today this medium is commercially produced by TRIOS s. r. o., Prague, Czech Republic and traded under the style of MKM ${ }^{\mathrm{TM}}$ MYPPN. Although the cultured material is treated by heat and the samples are grown on selective media with antibiotic supplements, resistant microbial strains inhibiting the growth of $P$. larvae can occasionally be detected on plates. In this sense, Alippi and Reynaldi (2006) mention some antagonists of Paenibacillus larvae and certain other Bacillus and Brevibacillus genus bacteria - namely they are Bacillus cereus, Bacillus megaterium, Bacillus subtilis, Bacillus pumilus, Bacillus licheniformis and Brevibacillus laterosporus.

\section{Materials and Methods}

The aim of the present study was to validate a new method of bee debris examination. The method (hereinafter referred to as the Tween method) is based on homogenizing the material by homogenization agent Tween 80 at $70 \pm$ $2{ }^{\circ} \mathrm{C}$ and transferring the spores from the homogenate to the liquid medium. Appropriate dilution, further treatment of this medium by the heat of $90 \pm 2{ }^{\circ} \mathrm{C}$ and its culturing on solid culture media make it possible to detect $P$. larvae spores and count them exactly. We also intended to compare the efficiency of the new method with the existing method based on dissolving of the wax component of debris in toluene or benzene (hereinafter referred to as the Toluene method).

Material, chemicals and culture media

Samples of debris and wax of honey bee were examined using sterile test tubes with airtight seals (placed in the stand), sterile scissors or scalpel to cut compact materials, sterile tweezers, disposable plastic teaspoons to spoon 
powdery materials, HELAGO HF-1200G (A\&D Instruments Limited, Oxford, UK) laboratory balance, sterile pipette (volume of $1 \mathrm{ml}, 0.1 \mathrm{ml}$ scale lines) to transfer the material to plates, $1 \mathrm{ml}$ calibrated disposable plastic pipettes with balloon, JULABO TW12 water bath (JULABO LABORTECHNIK GMBH, Seelbach, Germany), BT 120 thermostat for the temperature of $37 \pm 1{ }^{\circ} \mathrm{C}$ (EKOM s.r.o., Polná, Czech Republic), high-quality marker for the identification of plates and test tubes, sterile small containers for Tween 80, sterile Petri dishes, bent sterile plastic or glass sticks to spread liquids over agar media, bacteriological loops, Eppendorf tubes, API $50 \mathrm{CHB}$ kits for biochemical confirmation of bacilli (BioMérieux sa, Marcy 1'Etoile, France) or material and instrumentation for PCR. We also used distilled water, Tween 80 (Lach-Ner s.r.o., Neratovice, Czech Republic) and Toluene 99\% (Lach-Ner s.r.o., Neratovice, Czech Republic). The following culture media were used: 5\% sheep blood agar produced from Blood Agar Base №2 or Columbia Blood Agar Base manufactured commercially (Hi-Media Laboratories Pvt. Ltd., Mumbai, India) and modified MYPGP agar with nalidixic acid (Titěra and Haklová 2003). Modified MYPGP agar consisted of concentrated beef extract $3.5 \mathrm{ml}$, acid casein hydrolyzate $6.0 \mathrm{~g}$, soluble starch $0.5 \mathrm{~g}$, yeast autolyzate $15.0 \mathrm{~g}, \mathrm{~K}_{2} \mathrm{HPO}_{4} 3.0 \mathrm{~g}$, Na pyruvate $1.0 \mathrm{~g}$, agar $10.0 \mathrm{~g}$, distilled $\mathrm{H}_{2} \mathrm{O}$ $1,000.0 \mathrm{~g}$, nalidixic acid $30.0 \mathrm{mg}$ (dissolved in $1 \mathrm{ml}$ of $0.1 \mathrm{M} \mathrm{NaOH}$ ), glucose $2.0 \mathrm{~g}$ (sterilized separately). All ingredients (except glucose) should be carefully dissolved in distilled water and autoclaved at $121^{\circ} \mathrm{C}$ for $20 \mathrm{~min}$. Then glucose (sterilized separately) is added and the mixture is stirred thoroughly. After sterilization and addition of glucose, $\mathrm{NaOH}$ is used to stabilize $\mathrm{pH}$ between 7.2 and 7.5. Then the mixture is put onto sterile plates. The medium prepared this way can be stored at refrigerator temperature for three months and at room temperature (18 $-23^{\circ} \mathrm{C}$ ) for one month. Today, the aforementioned selective medium is manufactured commercially by TRIOS s. r. o., Prague, Czech Republic.

Examination procedure

One gram of debris or $1 \mathrm{~g}$ of wax is put to the test tube with airtight seal. Larger pieces of wax should be cut by sterile instruments into very small pieces (ideally up to $3 \mathrm{~mm}$ in size). Wax pieces contained in the debris do not have to be further cut because they are usually very small. The smaller the pieces, the easier and faster is the process of homogenization. Dry material prepared in this way should be stirred thoroughly and diluted with $8.5 \mathrm{ml}$ of sterile distilled water. The resulting suspension is then supplemented with $0.5 \mathrm{ml}$ of Tween 80 . Approximately 30 minutes before pipetting, the required volume of Tween 80 should be withdrawn from the original container, put into another sterile container with airtight seal and immersed in hot water bath $\left(70 \pm 2{ }^{\circ} \mathrm{C}\right)$ in order to reduce the viscosity of Tween 80 and facilitate its pipetting. The suspension of debris, water and Tween 80 is shaken thoroughly and the test tube is placed in hot water bath $\left(70 \pm 2^{\circ} \mathrm{C}\right)$ for $30 \mathrm{~min}$. If the wax dissolves slowly or there are pieces of wax larger than $5 \mathrm{~mm}$, the test tube could be left in water bath for up to 1 hour. While warming the sealed tube in water bath, it should be thoroughly shaken in longitudinal direction at least three times (or better, in several 5 to $30 \mathrm{~s}$ cycles 5 to $10 \mathrm{~min}$ apart). Such careful homogenization results in the development of homogenous greyish brown pulpy material which can harden as it cools down. Afterwards, tubes are removed from the water bath and let to cool down to room temperature at which they should be stored for $2-4 \mathrm{~h}$ until a sufficient amount of liquid is separated at the bottom of tubes. Then 2 $-5 \mathrm{ml}$ of this liquid is withdrawn with a disposable balloon pipette and mixed with the same volume of distilled water in another sterile sealable tube. Again, the resulting mixture should be shaken thoroughly in longitudinal direction for at least $5 \mathrm{~min}$ and put into a hot water bath $\left(90 \pm 2{ }^{\circ} \mathrm{C}\right)$. After $10 \mathrm{~min}$, the tubes with the stand are removed from the bath, let to cool down to room temperature and shaken again. Then the material is inoculated at $0.2 \mathrm{ml}$ doses to $3-5$ plates of MYPGP with nalidixic acid and at least one plate of blood agar serving as a control. Before culturing, the plates should be dried in a thermostat at $37 \pm 1{ }^{\circ} \mathrm{C}$. The drying time is selected in dependence on humidity of the culture medium surface (30 min is usually enough). Dishes must be identified accurately and any contamination or mistaking must be avoided during handling. The liquid is spread over the plates using a bent sterile plastic/glass stick or the tip of a pipette. The liquid is let to dry and the plates are incubated upside down at $37 \pm 1{ }^{\circ} \mathrm{C}$ for $5-8$ days. Starting on the second day of incubation, the plates should be checked for the presence of mould overgrowth. Plates with mould overgrowth must be removed immediately to avoid contamination of other plates. After incubation, the colonies are inspected and typical colonies are counted. The colonies are then isolated and subjected to biochemical confirmation or suspended in Eppendorf tubes in a small amount of sterile redistilled water to perform typing by the PCR method. Biochemical confirmation is usually more labour-consuming, more expensive and less reliable, and it cannot be used in overgrowing colonies. The experiment was evaluated using the paired $t$-test (Anděl 1978). We started our evaluation with the hypothesis $\left(\mathrm{H}_{0}\right)$ that the effectiveness of the Toluene method (Titerra and Haklová 2003) in detecting the spores will be significantly higher or comparable to the Tween method. An alternative hypothesis $\left(\mathrm{H}_{1}\right)$ assumed that the Tween method would be significantly more effective in detecting $P$. larvae spores. Critical value for rejecting the hypothesis $\mathrm{H}_{0}$ (the value was determined by tables for work with 19 positive samples) was $\mathrm{t}_{18} ;{ }_{0.95}=-1.734$. Hypothesis $\mathrm{H}_{0}$ would be rejected, if $\mathrm{t} \leq-1.734$. Hypothesis $\mathrm{H}_{0}$ would not be rejected, if

$\mathrm{t}>-1.734$. The calculation was performed as per the formula $t=\frac{\bar{x}}{\sqrt{s^{2}}} \cdot \sqrt{n}$ where $\bar{x}$ was an arithmetic mean of differences of counts of colonies detected by the Toluene method $\left(y_{i}\right)$ and the Tween method $\left(\mathrm{z}_{\mathrm{i}}\right)$;

$\bar{x}=\frac{\sum_{i}^{n}\left(y_{i}-z_{i}\right)}{n}$, or $\bar{x}=\frac{\sum_{i}^{n} x_{i}}{n}$, where $\mathrm{n}$ was the number of samples we worked with; sample variance $\mathrm{s}^{2}$ was then computed as $\mathrm{s}^{2}=\frac{\sum_{i}^{n}\left(x_{i}-\bar{x}\right)}{n-1}$; and $\sqrt{s^{2}}$ was the sampling standard deviation. 
Examination method

The samples of bee debris were examined by our own Tween method described above. At the same time, the samples were examined by the commonly used Toluene method designed by Titěra and Haklová (2003). In order to ensure comparable results, we dissolved $1 \mathrm{~g}$ of debris in $9 \mathrm{ml}$ of toluene. Other dilutions were similar to the Tween method. Diluted extracts were treated in a hot water bath $\left(90 \pm 2{ }^{\circ} \mathrm{C}\right)$ for 10 min (the Tween method), or 5 min (the Toluene method) (Titěra and Haklová 2003). After the extracts cooled down, they were inoculated at $0.2 \mathrm{ml}$ doses on three dry plates of MYPGP with nalidixic acid and 1 blood agar. The extracts were inoculated separately for each method and each sample. Drops of extract were spread thoroughly by the tip of the pipette and let to dry on the surface of the plates. Then all the inoculated plates were incubated for 8 days at $37 \pm 1^{\circ} \mathrm{C}$. The numbers of colonies on all three plates of MYPGP with nalidixic acid (Titěra and Haklová 2003) were summarized for each sample and each method separately. On the basis of the number of colonies, the arithmetic mean was calculated separately for each sample and each method. Blood agar plate always served as a contamination control. Counted colonies were identified by the PCR method as Paenibacillus larvae and the results were recorded in tables and statistically evaluated.

Table 1. Count of Paenibacillus larvae colonies on MYPGP agar with nalidixic acid (Titěra and Haklová 2003) from bee debris processed by the Toluene and Tween 80 methods

\begin{tabular}{|c|c|c|c|c|c|}
\hline Sample No. & \multicolumn{2}{|c|}{ Count of colonies on plate } & Sample No. & \multicolumn{2}{c|}{ Count of colonies on plate } \\
\hline & Toluene method & Tween 80 method & & Toluene method & Tween 80 method \\
\hline 1 & 2613 & 2720 & 11 & 216 & 2080 \\
\hline 2 & 29 & 1156 & 12 & 50 & 708 \\
\hline 3 & 187 & 2964 & 13 & 165 & 1376 \\
\hline 4 & 57 & 3567 & 14 & 1696 & 1004 \\
\hline 5 & 0 & 3 & 15 & 1168 & 1850 \\
\hline 6 & 3818 & 3969 & 16 & 2784 & 2924 \\
\hline 7 & 2361 & 2311 & 17 & 2707 & 2576 \\
\hline 8 & 62 & 2613 & 18 & 1536 & 1048 \\
\hline 9 & 45 & 2562 & 19 & 3478 & 2856 \\
\hline 10 & 1808 & 3768 & & & \\
\hline
\end{tabular}

\section{Results and Discussion}

\section{Interpretation of results}

The examination results can be expressed quantitatively, qualitatively or semiquantitatively. In quantitative interpretation, the numbers of colonies counted on plates and confirmed as $P$. larvae are multiplied by 100 . The result obtained this way represents the number of spores in $1 \mathrm{~g}$ of examined material. Qualitative interpretation of results is expressed by the following statement: "Paenibacillus larvae was (or was not) detected in the submitted sample." Semiquantitative interpretation of the growth intensity can be expressed by one to four crosses written in superscript behind the causative agent name in the examination protocol: $+=$ sporadic (up to 10 colonies per plate); $++=$ weak $(11-50$ colonies per plate); $+++=$ moderate $(51-300$ colonies per plate); and $++++=$ strong (more than 300 colonies per plate). In the present study, the results were expressed quantitatively. For the purposes of statistical evaluation, we used only counts of colonies that grew on plates. Table 1 indicates that the Toluene method showed a higher mean count of colonies per plate in 6 cases. On the contrary, the Tween method showed a higher mean count of colonies per plate in 13 cases. Tween final counts of $P$. larvae colonies were in some cases up to 63 times higher than Toluene counts. In one case, the Toluene method identified the particular sample (no. 5) as negative, while the Tween method identified the same sample as positive. On the basis of comparison of counts of colonies that grew under the conditions of the Toluene and Tween methods and using the paired $t$-test, we calculated $\mathrm{t}=-3.524$. This means that $\mathrm{t}<$ table value $\mathrm{t}_{18: 0.95}$. It follows that hypothesis $\mathrm{H}_{0}$ is rejected and alternative $\mathrm{H}_{1}$ is valid, which means that our Tween method is statistically significantly more effective in 
detecting $P$. larvae spores that the Toluene method (Titěra and Haklová 2003). This fact might be explained by high aggressiveness of toluene that might kill a part of spore-forming microorganisms in one of the sporulation stages. It is also possible that toluene residues on plates with agar culture media negatively influence the germinating activity and growth of microorganisms. When evaluating and comparing both methods, one should be aware of the fact that bee debris, unlike honey or pollen, is a very non-homogenous material both from the viewpoint of composition and the incidence of Paenibacillus larvae spores. Presumably, a part of the debris consisting of remains of various development stages of bees, cappings and infected cells will contain more spores than beeswax, pollen or remains of adult bodies that can make up a considerable part of debris. The content of spores in individual weight fractions of one sample could differ significantly, especially in early disease stages. This must be kept in mind when processing and evaluating the results. It could also explain the fact that the Toluene method showed higher spore counts in six cases. Moreover, the sample weighing accuracy should be taken into account, especially in the debris with high density of spores. On the basis of our experience supported by verification of a number of samples at other research sites, we recommend examining bee debris by the Tween method. The benefits of this method include significantly higher efficacy in detecting P. larvae spores, better environment compatibility, easier waste disposal and fire protection, higher level of laboratory staff safety and higher cost-effectiveness. During the development of the new examination method, we also tested the possibility to grow microorganisms in liquid media with glucose and nalidixic acid in order to significantly improve the diagnostics in materials with very small quantities of spores (less than $10^{2} / \mathrm{g}$ ). Unfortunately, this method was hindered by the incidence of non-target aerobic sporulates, microbes and moulds that probably produce chemicals suppressing the growth of $P$. larvae. We detected 5 bacterial species with varying antagonistic action on $P$. larvae. These are Bacillus cereus, Bacillus pumilus, Bacillus licheniformis, Brevibacillus brevis and, less significantly, Kocuria varians. The most often diagnosed moulds were $A$. niger and Mucor sp. These observations confirm the results of Alippi a Reynaldi (2006). We believe that future efforts should be directed toward generating an improved selective agar media that will effectively prevent the growth of non-target spore-forming microorganisms and moulds that can easily destroy our work.

\section{Detekce spor Paenibacillus larvae ve včelí měli a vosku metodou Tween 80}

Cílem práce bylo ověření nové metody detekce spor Paenibacillus larvae ve včelí měli a vosku a její srovnání s původní metodou doposud používanou v ČR využívající toluen nebo benzen k rozpuštění voskových složek vzorku a uvolnění spor do tekutého média. Nová metoda je založena na principu homogenizace materiálu za pomoci destilované vody a homogenizačního činidla Tween 80 při teplotě $70 \pm 2^{\circ} \mathrm{C}$. Spory jsou ze vzniklé suspenze převedeny do tekutého média, které je naředěno a ošetřeno teplotou $90 \pm 2{ }^{\circ} \mathrm{C}$ za účelem likvidace vegetativní saprofytické mikroflory. Objem $0.2 \mathrm{ml}$ tohoto média je následně inokulován na pevné půdy (krevní agar a MYPGP agar s kyselinou nalidixovou). Po 5 - 8 denní inkubaci při $37 \pm 1{ }^{\circ} \mathrm{C}$ jsou suspektní kolonie P.larvae spočítány a je provedena konfirmace. Počet kolonií vynásobený 100 vyjadřuje počet spor v $1 \mathrm{~g}$ materiálu. K porovnání obou metod bylo využito 11 kontrolních vzorků včelí měli z kruhového testu a 10 prokazatelně pozitivních terénních vzorků měli obsahujících spory P.larvae. Nová metoda byla samostatně testována na dalších 1509 terénních vzorcích zimní včelí měli, které byly vyšetřeny v období 1. 1. 2006 - 10. 5. 2006 a které byly odebrány v ochranných pásmech moru včelího plodu. Z těchto 1509 terénních vzorků byl ve 46 prrípadech zaznamenán pozitivní nález $P$. larvae. Srovnáním počtů spor zjištěných paralelně oběma metodami u kontrolních 21 vzorků a jejich porovnáním statistickou metodou párového $t$-testu bylo zjiš- 
těno, že metoda tweenová poskytla výsledky s prokazatelně statisticky významně vyšším záchytem počtu spor $P$. larvae ve vyšetřovaném materiálu, než stávající toluenová metoda (zjištěná hodnota $\mathrm{t}=-3,524)$. Výsledky testů ukazují, že metoda tweenová by po odzkoušení a ověření i na jiných pracovištích mohla být vhodná pro vyšetření včelích mělí a vosku. Metoda tweenová je narozdíl od metody využívající organických rozpouštědel přijatelnější z hlediska požární ochrany, ochrany životního prostředí, likvidace odpadů i z hlediska ochrany zdraví personálu laboratoří, který tato vyšetření provádí. Z vědeckého hlediska by mohla hrát významnou roli ve včasné diagnostice a následném tlumení výskytu moru včelího plodu nejen v České republice ale i jinde ve světě.

\section{Acknowledgement}

Special acknowledgement to Doc. RNDr. Pavla Kunderová, CSc. and RNDr. Eva Fišerová, Ph.D. from the Department of Mathematical Analysis and Applications of Mathematics of the Faculty of Science of the Palacký University Olomouc for helping me with statistical evaluation of the study results. Also, I thank Ing. Dalibor Titěra and Marcela Haklová from the Bee Research Institute in Dol for their expert assistance and practical advice in the area of laboratory diagnostics of American foulbrood and apiculture, and Prof. MVDr. Eva Baranyiová, the editor-in-chief of Acta Veterinaria Brno for valuable guidance regarding the composition of this study.

\section{References}

ALIPPI AM 1995: Detection of B.larvae spores in Argentinian honeys by using a semi-selective medium. Microbiologia 11: 343-350

ALIPPI AM, REYNALDI FJ 2006: Inhibition of the growth of Paenibacillus larvae, the causal agent of American foulbrood of honeybees, by selected strains of aerobic spore-forming bacteria isolated from apiarian sources. J Invertebr Pathol 91: 141-146

ANDĚL J 1978: Párový $t$-test. In Matematická statistika, SNTL Praha, pp. 90-91

GOCHNAUER TA, CORNER J 1974: Detection and identification of B. larvae in a commercial sample of beecollected pollen. J Apicult Res 13: 265-267

HAKLOVÁ M 2006: The use of Commercial Nutrient Agar TRIOS for diagnosis of American foulbrood in Honeybees. Proceedings of the Second European Conference of Apidology Eur Bee. Prague, Czech Republic, p. 41

HANSEN H, BRØDSGAARD CJ 1999: American foulbrood: A review of its biology, diagnosis and control. Bee World 80: 5-23

HORNITZKY MAZ, NICHOLLS J 1993: J Medium is superior to sheep blood agar and brain heart infusion agar for the isolation of B. larvae from honey samples. J Apicult Res 32: 51-52

TITĚRA D, HAKLOVÁ M 2003: Detection method of Paenibacillus larvae from beehive winter debris. Apiacta 38: $131-133$

TITĚRA D, HAKLOVÁ M 2005: Stanovení Paenibacillus larvae, ssp. v měli a vosku. Předmět zkoušky med, měl, vosk. Standardní operační postup Výzkumný ústav včelařský s.r.o. Dol u Prahy, MI_01_PL, AZ 5, pp. 1-5 